\title{
Lehmän hyvinvointi automaattisessa lypsyjärjestelmässä
}

\author{
Satu Raussi ${ }^{1,2)}$ ja Jutta Kaihilahti ${ }^{1,3)}$ \\ ${ }^{1)}$ MTT Maatalousteknologian tutkimus (Vakola),Vakolantie 55, 03400 Vihti, satu.raussi@mtt.fi \\ ${ }^{2)}$ Helsingin yliopisto, Kliinisen eläinlääketieteen laitos, Kotieläinhygienia, PL 57, 00014 Helsingin \\ yliopisto \\ ${ }^{3)}$ Hämeen ammattikorkeakoulu, Mustiala
}

\begin{abstract}
Johdanto
Automaattisia lypsyjärjestelmiä asennetaan jatkuvasti maissa, joissa työvoima on kallista ja ammattitaitoisesta työvoimasta on pulaa. Karjanhoitaja hakee järjestelmästä helpotusta ja muutosta rutiininomaiseen lypsytyöhön. Lehmien maitotuotos voi myös parantua useampien lypsykertojen myötä. Automaattisessa lypsyjärjestelmässä lehmä ja hoitaja ovat uuden teknologian käyttäjiä. Maidontuotannon laatuun kuuluu hyvinvointitarkastelu molempien käyttäjien osalta. Tässä tiivistelmässä tarkastellaan järjestelmän erityispiirteitä lehmän hyvinvoinnin näkökulmasta.

Lehmämäärän tilaa kohti kasvaessa automaattilypsy kiinnostaa myös suomalaisia tiloja. Ensimmäisiä järjestelmiä onkin seurattu Suomessa reilun vuoden verran. Tutkimusta tehdään Helsingin yliopiston opetus- ja tutkimustilalla Siuntion Suitiassa ja seurannassa on ollut mukana kaksi ensimmäistä järjestelmän hankkinutta yksityistilaa.
\end{abstract}

\section{Oppiminen ja opettaminen}

Rauhallisuus, kärsivällisyys ja houkuttelu ovat avainsanoja lehmän opettamisessa automaattiseen lypsyyn. Automaattilypsyn aloittavalla tilalla on usein uusi navetta, jolloin lehmille koko navettatila (lattiamateriaalit, makuuparret, ruokintapöytä ja väkirehukioskit, ilmastointi, kulkutiet, portit sekä tietenkin itse lypsypaikka ja lypsykone eli -robotti) on uutta.

Lehmä kannattaa aina ensin houkutella väkirehulla uusista porteista läpi. Samoin lypsypaikkaan totuttelu kannattaa tehdä rehulla houkuttelemalla pakottamisen sijaan. Jos robotille meno on alusta saakka ollut lehmälle vapaaehtoista, ei muistiin jää ikäviä mielikuvia lypsypaikasta ja lehmä oppii itsenäisesti pelkäämättä tulemaan lypsylle. Opettamisessa kannattaa myös käyttää hyväksi karjan rohkeimpia ja uteliaimpia yksilöitä. Vaikka jokainen lehmä on yksilö on lehmä kuitenkin vahvasti laumaeläin ja tarkkailee ryhmänsä muiden jäsenten tekemisiä. Rohkeimpien yksilöiden uskallettua ensin uuteen paikkaan voi kynnys kokeilemiseen muilla alentua.

\section{Hyvinvoinnin toteutuminen}

Lehmän hyvinvoinnin kannalta järjestelmän tärkein osa on ammattitaitoinen karjanhoitaja. Vaikka lypsytyön tekeekin lypsyrobotti, niin hoitaja vastaa edelleen eläinten ruokinnasta, terveydestä, kiimantarkkailusta, eläinten, navetan ja lypsypaikan puhtaudesta, hyvästä lypsyhygieniasta ja hyvistä suhteista eläimiinsä. Automaattilypsyssä tulee ihmis-eläinsuhteista pitää erityistä huolta. Lehmät on totutettava myös ihmiskäsittelyyn, jotta vältytään pelolta ja sen aiheuttamalta stressiltä tulevissa käsittelytilanteissa.

Lehmän hyvinvointiin robottinavetoissa liittyy olennaisesti navetan lehmäliikenteen järjestäminen. Lehmäliikenne voi olla eri tavoin ohjattua, mikä tarkoittaa sitä, että navettaan on asennettu paluunestoportteja, jotka ohitettuaan lehmät eivät pääse enää samaa reittiä takaisin. Näin lehmät liikkuvat ohjatusti makuu- ja ruokinta-alueiden sekä lypsypaikan välillä. Täysin ohjatun lehmäliikenteen vaihtoehtona robottinavetoissa käytetään myös liikennettä, jossa lehmät saavat liikkua vapaasti karkearehunsyönti- ja makuualueiden välillä.

Lehmille tulisi olla navetassa rajoituksetta tarjolla karkearehua ja vettä. Karkearehun syöntipaikkoja tulisi olla riittävästi ja makuupaikkoja vähintään yksi eläintä kohti. Lypsyrobotille lehmä houkutellaan väkirehulla. Pelkkä lypsetyksi tuleminen ei riitä motivoimaan lehmää lypsyrobotille menoon, varsinkaan silloin, kun korkean tuotoksen vaihe on ohitettu.

Lehmien tulisi saada laiduntaa kesällä. Laidunnuksen ja automaattilypsyn järjestäminen on mahdollista, mikäli laitumet sijaitsevat lähellä navettaa. Laidunnuksen ja automaattilypsyn yhdistäminen on parhaillaan tutkimuksen kohteena monessa maassa. Ensi kesänä on Suitiassakin tarkoitus tutkia vapaata ja rajoitettua laidunnusta automaattilypsyn yhteydessä. 